\title{
КОНЦЕПЦІЯ РЕФОРМУВАННЯ ОРГАНІВ КРИМІНАЛЬНОӤ ЮСТИЦІЇ В КОНТЕКСТІ ПРОТИДІЇ КОРУПЦІї
}

\begin{abstract}
ОДНОЛЬКО Інна Валентинівна - кандидат юридичних наук, доцент, викладач відділу підготовки прокурорів з підтримання публічного обвинувачення в суді Інституту спеціальної підготовки Національної академії прокуратури України
\end{abstract}

DOI:10.32782/LAW.2020.1.25

УДК 343.97

\begin{abstract}
Статтю присвячено розгляду конщепийі ребормування органів кримінальной юстищї в контексті протидії корупиї.

Наведено думки вчених стосовно того, що $\epsilon$ кримінальною юстииією та, відповідно, органами зазначеноӥ інституиій, а також про реборми органів кримінальної юстицій, проведені за часів незалежності Украӥни, та їх результати. Вказано обов'язкові завдання, які повинні бути передбачені в будь-якій концепиії ребормування органів кримінальної юстииї в контексті протидій корупцй.

Автор розкриває теоретичне підгрунтя правової категорї органів кримінальной юстииї, а також детально аналізує місие та роль Начіонального антикорупиійного бюро України в системі органів кримінальної юсmuиiï.
\end{abstract}

Зауважено, що реформування органів кримінальної юстииї передбачає певне перезавантаження та запровадження нових методик діяльності. Стверджується, що ребормування органів кримінальної юстииї може слугувати відправною точкою для подальших перетворень в інших сберах діяльності нашої держави.

Як підсумок визначено, що результатом проведення ребормування органів кримінальної юстииї в контексті протидій корупцій, при застосуванні будь-якої концепцї, має стати перетворення правоохоронних органів із суто каральних та таких, що здійснюють переслідування за допомогою жорстких методів, на органи, головною метою яких є відновлення порушених прав людини та максимальне недопущення таких порушень взагалі

Ключові слова: корупиія, протидія корупиї, органи кримінальної юстищї, реборма, антикорупиійне законодавство.

Корупційна злочинність, як і власне корупція, поступово руйнує державу. Сучасні дослідження вже досить чітко дали зрозуміти, яку небезпеку становить корупція для держави та суспільства. Останніми роками державні інституції дедалі частіше наголошують на необхідності подолання корупційних проявів в Україні. У своїх виступах та доповідях про першочерговість цього завдання зазначали й колишній Президент України П. О. Порошенко, й теперішній В. О. Зеленський. Гаранти Конституції відмічають, що подолання корупції 6 пріоритетним напрямом у роботі органів кримінальної юстиції. Очевидно, що народ України очікує від них реалізації цього завдання, щоб наша держава нарешті позбавилася згубних корупційних проявів чи хоча 6 звела їх до допустимого мінімуму.

Цілком природно, що без подолання корупції Україні майже неможливо увійти в когорту провідних держав світу, й це при тому, що в нашій державі 6 всі початкові умови для того, аби стати одним 3 лідерів європейського континенту [6, с. 8].

3 плином часу та розвитком державності в Україні поступово змінюються місце та роль органів кримінальної юстиції, які покликані протидіяти корупції. Діяльність ба- 
гатьох із них наповнюеться новим змістом, а реалізація завдань, покладених на той чи інший орган, постає чи не головною умовою розбудови правової держави.

Вітчизняні вчені відмічають необхідність реформування органів кримінальної юстиції, врегулювання та оптимізації їх діяльності 3 метою відповідності вимогам часу. Як уже склалося в нашій державі за певною традицією, будь-яка реформа - це трудомісткий процес, до реалізації якого державні посадовці підходять вкрай неохоче та максимально затягуючи будь-які нововведення.

Необхідно зауважити, що концепція реформування органів кримінальної юстиції в контексті їх протидії корупції повинна бути системною, комплексною та мати належне науково-теоретичне обгрунтування. Не менш важливим 6 і той факт, що цей процес повинен відбуватися поступово. Разом iз тим у жодному разі не варто кардинально викорінювати старе та бездумно замінювати його на нове. Адже сучасні органи кримінальної юстиції напрацювали певний досвід, втратити який є неприпустимо.

Якщо казати про актуальність даного дослідження, то вона пояснюється необхідністю наукового висвітлення різних концепцій реформування органів кримінальної юстиції в контексті протидії корупції, тому що такого реформування вимагають сучасні умови життя. Проте окреслена проблема ще недостатньо вивчена. Тому спробуємо систематизувати наявну інформацію стосовно зазначеного питання та запропонувати власне бачення способів його вирішення.

Розгляду різних аспектів діяльності органів кримінальної юстиції присвятили свої роботи такі вчені, як Т. Г. Андрусяк, М. І. Байтін, О. М. Бандурка, І. А. Бачило, В. Т. Білоус, А. В. Боровик, О. Ю. Бусол, Е. М. Блажівський, С. В. Ківалов, М. І. Козюбра, І. М. Козьяков, М. І. Мельник, Д. Г. Михайленко, М. I. Хавронюк, Н. М. Ярмиш та інші.

Ці науковці внесли вагомий внесок у висвітлення діяльності органів кримінальної юстиції, проте саме питання щодо концепцій реформування органів кримінальної юстиції в контексті протидії корупції не досліджені комплексно.
Метою статті є визначення поняття органів кримінальної юстиції, їх функціонування в контексті протидії корупції та огляд тих концепцій реформування органів кримінальної юстиції України в контексті протидії корупції, які наразі існують. Для досягнення окресленої мети ставимо завдання - дослідити науково-теоретичну базу, що стосується органів кримінальної юстиції, здійснити аналіз концепцій реформування органів кримінальної юстиції в контексті протидії корупції в нашій державі та виявити найбільш вдалі з них.

Переходячи до викладу основного матеріалу, передусім слід вказати, що є кримінальною юстицією та, відповідно, органами зазначеної інституції.

О. Кальман відмічає, що кримінальна юстиція включає в себе діяльність тих органів, що безпосередньо здійснюють (ведуть) кримінальний процес [2, с. 33].

С. Ківалов стверджує, що до кримінальної юстиції належать ті органи, які діють у сфері кримінального судочинства [3, с. 7].

Частина інших науковців схильна вважати, що до органів кримінальної юстиції належать усі державні органи, які забезпечують законність та правопорядок на теренах нашої держави. На наш погляд, саме це визначення є найбільш узагальненим та вдалим. Виходить, що органами кримінальної юстиції в контексті протидії корупції в Україні виступають усі ті державні органи, що забезпечують законність та правопорядок у сфері боротьби з корупцією.

Слід зазначити, що думки про реформування кримінальної юстиції та пріоритетне значення цього процесу з'являються 3 відносною періодичністю вже досить давно. Так, у квітні 2008 року було видано Указ Президента України, яким затверджено Концепцію реформування кримінальної юстиції України, відповідно до якої нашій державі необхідно було провести комплексну реформу органів кримінальної юстиції задля приведення останніх до міжнародних стандартів. Невдовзі Кабінет Міністрів України затвердив План заходів щодо реалізації Концепції реформування кримінальної юстиції України. Координацію щодо реформування органів кримінальної юсти- 


\section{Кримінальне право, кримінальний процес та криміналістика}

ції було покладено на Міністерство юстиції України [7].

В. Шакун зазначає, що останніми роками в українському суспільстві дедалі зростає попит на певні державні перетворення, які б сприяли покращенню рівня життя та відповідали прагненню до євроінтеграції. Звісно, громада цікавиться й питаннями реформування органів кримінальної юстиції, адже результати діяльності зазначених органів досить рідко задовольняють вимоги населення [10, с. 138].

Організація влади в Україні недосконала, і це - факт. Хоч останніми роками і відбулися певні зрушення, українська спільнота все одно вимагає більш якісної роботи від державної влади та суміжних державних інституцій, що в цілому є абсолютно нормальним явищем. Відповідно, недосконалою є й система органів кримінальної юстиції в нашій країні (в тому числі у контексті їх протидії корупційній злочинності).

Існує думка, з якою складно не погодитися, що чинна система кримінальної юстиції не завжди відповідає сучасному рівню життя всередині держави, а нової концепції реформування, яка 6 враховувала всі особливості українського буття, так і не розроблено.

Система кримінальної юстиції в контексті протидії корупції в сучасній Україні керується застарілими положеннями, а удосконалення законодавства, яке регулює діяльність органів кримінальної юстиції, не завжди відрізняється логічністю та системністю.

У нашій країні усталеною є думка про виокремлення трьох груп суб'єктів, уповноважених на протидію та запобігання корупційним проявам. Так, це суб'єкти із загальними повноваженнями (до них належать Президент України, Верховна Рада України, Кабінет Міністрів України, Генеральний прокурор України - суб'єкти, не створені спеціально для безпосередньої протидії корупційним проявам, тому вони називаються загальними); суб'єкти із спеціальними повноваженнями (до них відносяться: органи прокуратури, органи Національної поліції України, Державне бюро розслідувань (ДБР), Національне антикорупційне бюро
України (НАБУ), Національне агентство 3 питань запобігання корупції - зазначені суб'єкти визначені Законом України «Про запобігання корупції та уповноважені безпосередньо виявляти, розслідувати і припиняти корупційні злочини); суб'єкти, які мають повноваження щодо участі в певних антикорупційних заходах (до них належать: державні органи влади, органи місцевого самоврядування, підприємства, установи, організації всіх форм власності та будь-якої організаційно-правової форми, окремі громадяни та громадські формування - ці органи прямо не уповноважені на протидію корупційним проявам, але від них може надійти певний сигнал до органів із спеціальними повноваженнями й зазначені суб'єкти можуть певним чином сприяти відновленню порушених прав, брати участь у заходах).

3 останніх важливих нововведень, пов'язаних із діяльністю системи органів кримінальної юстиції в контексті протидії корупції, слід назвати створення нового правоохоронного органу зі спеціальними повноваженнями по боротьбі з корупцією, яким стало Національне антикорупційне бюро України. На цей відносно нещодавно створений орган покладалися великі надії громадян нашої держави, адже йшлося про те, що НАБУ вживатиме жорстких заходів 3 викорінення корупції та не буде мати авторитетів. Насправді ж діяльність зазначеного державного органу вже зазнала критики за інертність та малоефективність. Заради справедливості варто зауважити, що здійснювати свою діяльність НАБУ доводиться під постійним тиском політичних сил, які прагнуть підпорядкувати цей орган своїм інтересам. Протистояти впливовим політикам у нашій державі вкрай важко, а відтак буденна робота НАБУ - це не тільки протидія та запобігання корупції, а й боротьба 3 політичними силами та впливовими особами за збереження власної незалежності.

Як часто буває в Україні, добру ініціативу псує погана реалізація. Так і у випадку з НАБУ - чудову ідею створення цього антикорупційного органу дещо зіпсував спеціальний закон, який містив чимало недоліків. Тобто НАБУ не отримало належної законодавчої (нормативної) підтримки. Так, 
із тексту Закону України «Про Національне антикорупційне бюро України» [8] вбачається певний конфлікт у існуванні одночасно таких органів, як НАБУ та спеціалізована антикорупційна прокуратура.

Так, відповідними змінами до деяких законодавчих актів України щодо вдосконалення окремих положень кримінального процесуального законодавства від 4 жовтня 2019 року, розширено повноваження Генерального прокурора або особи, яка виконує його обов'язки, чи керівника Спеціалізованої антикорупційної прокуратури в частині скасування незаконних та необгрунтованих постанов детективів НАБУ та прокурорів Спеціалізованої антикорупційної прокуратури, чого не було в попередній редакції частини 6 статті 36 КПК України (частина шоста статті 36 із змінами, внесеними згідно із Законом № 187-IX від 04.10.2019).

Значною проблемою стало й те, що додався ще один орган досудового розслідування, проте незмінною залишилася кількість слідчих суддів у багатьох районних судах різних міст нашої країни. У результаті певні слідчі судді повинні майже цілодобово розглядати подання детективів НАБУ на проведення тих чи інших процесуальних, слідчих дій [10, с. 140].

Існують певні питання й щодо професійної підготовки детективів НАБУ. Зрозуміло, що для якісного виконання професійних обов'язків із викорінення явища корупції детективи НАБУ повинні мати грунтовні знання у різних сферах життя (економічній, соціальній тощо).

Цікаво, що робота НАБУ передбачає залучення негласних працівників, що повинно допомогти у виявленні та розслідуванні більшої кількості корупційних злочинів. Але ж залучені до роботи особи зазвичай не мають спеціальної освіти та належного досвіду. Водночас ті, про кого збирається матеріал, переважно - впливові та заможні люди. Відповідно, вони майже стовідсотково мають кваліфікованих адвокатів із великим досвідом.

Варто пам'ятати, що головна мета реформування системи органів кримінальної юстиції - це підвищення ефективності їхньої роботи задля досягнення високих результа- тів. Багато в чому іiі реалізація залежить від ефективності загального державного управління.

Концепція реформування органів кримінальної юстиції в контексті протидії корупційній злочинності передусім повинна передбачати оптимізацію загальної кількості органів виконавчої влади та безпосередньо органів забезпечення правопорядку із вектором на їх зменшення, аби відмовитися від дублювання певних відомств і структур [10, c. 144].

Взагалі, питання реформування сучасних органів кримінальної юстиції, на які покладено обов'язок протидії корупції, постало внаслідок низької ефективності їхньої роботи. Їх працівники подекуди самі причетні до корупційних правопорушень та часто неспроможні виконати ті завдання, які на них покладено законодавцем.

За час незалежності України органи кримінальної юстиції неодноразово реформувалися, часто висувалися різноманітні концепції та програми розвитку, але, напевно, жодного разу до зазначеного реформування не підходили системно та виважено, зазвичай маючи на меті насамперед досягнення певних політичних цілей [1, с. 207].

Традиційно органи кримінальної юстиції називають правоохоронними, й система зазначених органів у нашій державі доволі розгалужена. Проте якою 6 розгалуженою вона була 6 , все одно характерним залишається певний негативний, ще радянський, аспект - органи кримінальної юстиції так i не стали інституцією, яка 6 намагалася допомогти у відновленні порушених прав, а залишилися органами переслідування та покарання. Зрозуміло, що пряник повинен бути поєднаний із батогом, але система українських органів кримінальної юстиції часто користується лише батогом. Ще більш важливо, що пересічні громадяни, населення України, здебільшого не довіряють працівникам органів кримінальної юстиції, вважаючи їх досить корумпованими, а як відомо, корумпований орган не буде ефективно протидіяти корупції. Переконує населення в правильності його висновків і той факт, що які 6 реформи не здійснювалися, які 6 нові органи не створювалися, загальний рівень 


\section{Кримінальне право, кримінальний процес та криміналістика}

корупції в державі не зменшується, а навіть зростає. Про яку довіру в такому випадку може йтися?

Концепція реформування органів кримінальної юстиції в контексті протидії корупції повинна передбачати:

• досягнення конституційно закріпленого принципу верховенства права;

- досягнення належної поваги до прав та свобод громадянина, його честі та гідності;

• додержання Конституції України [4] та інших Законів України;

- дотримання принципів та норм міжнародного права;

- співпрацю з іншими органами державної влади, органами місцевого самоврядування тощо;

- заміну застарілих кадрів новими, професійними, з належною підготовкою;

- співробітництво із органами кримінальної юстиції інших держав та загальноєвропейськими (на кшталт Інтерполу);

- виведення органів кримінальної юстиції з-під впливу політичних партій, рухів;

- запровадження реальної невідворотності покарання за вчинене правопорушення;

- взаємодію органів кримінальної юстиції із громадянським суспільством щодо розслідування корупційних злочинів та запобігання поширенню корупції;

- антикорупційну спрямованість діяльності всіх правоохоронних органів тощо [1, c. 211].

Реформування органів кримінальної юстиції є одним із першочергових кроків для розбудови демократичної країни, де права та свободи людини будуть реально захищені законом.

Ті реформи кримінальної юстиції, що раніше мали місце в Україні, зазвичай носили безсистемний характер, а відтак не сприяли жодним позитивним зрушенням. Концепція реформування органів кримінальної юстиції має бути спрямована на досягнення більшої ефективності діяльності цих органів, усунення суперечностей між їх повноваженнями та забезпечення достатнього фінансування.

Реформування органів кримінальної юстиції передбачає певне перезавантаження та запровадження нових методик діяльнос- ті. Цілком можна запозичити досвід деяких країн, де вдалося грамотно реформувати кримінальну юстицію, як-от, наприклад, ᄉатвї [5].

Очевидно, що будь-яка концепція реформування органів кримінальної юстиції в контексті протидії корупції повинна містити обгрунтування про функціонування в системі кримінальної юстиції спеціалізованого антикорупційного органу з повноваженнями, зокрема, щодо проведення досудового розслідування та координації діяльності у цій сфері [9]. Наразі подібним органом виступає НАБУ.

Отже, з огляду на викладене можна дійти висновку, що на сьогодні система органів кримінальної юстиції в Україні є ускладненою, неефективною та такою, що несе фінансове обтяження для держави. Загальний рівень злочинності в країні, в тому числі корупційної, наочно підтвердив неспроможність сучасної системи органів кримінальної юстиції виконувати завдання, покладені на неї законодавством.

Відтак сучасне українське буття вимагає змін. Концепція реформування органів кримінальної юстиції в контексті протидії корупції повинна грунтуватися на довірі до суспільства, утвердженні захисту прав i свобод людини і громадянина та невідворотності покарання за вчинене корупційне правопорушення.

Реформування органів кримінальної юстиції може слугувати відправною точкою для подальших перетворень у нашій державі в інших сферах життя. Правова держава - це держава, де дотримано прав і свобод кожного члена суспільства, а повноваження кожного органу правопорядку розподілені належним чином.

Результатом проведення реформування органів кримінальної юстиції в контексті протидії корупції, при застосуванні будьякої концепції, має стати перетворення правоохоронних органів із суто каральних i таких, що здійснюють переслідування за допомогою жорстких методів, на органи, головною метою яких є відновлення порушених прав людини та максимальне недопущення таких порушень взагалі. 


\section{Аітература}

1. Головач А. В. Реформування органів кримінальної юстиції - справа невідкладна [Електронний ресурс] / А. В. Головач // Форум права. - 2010. - № 4. - С. 207-213. - Режим доступу: http://nbuv.gov.ua/UJRN/FP index

2. Кальман О. Кримінологічні проблеми реформування органів кримінальної юстиції України/ О. Кальман, О. Чікін // Право України. - 2010. - № 11. - С. 33-38

3. Ківалов С. Українська юстиція на шляху до Свропейських стандартів/ С.Ківалов // Голос України. - 2006. - № 86 (3836). - C.7

4. Конституція України : Офіційний вісник України від 01.10.2010 - 2010 р., / № $72 / 1$ Спеціальний випуск/, стор. 15, стаття 2598 (дата звернення 21.01.2020).

5. Кохан В. П. Реформування органів кримінальної юстиції: досвід Аатвії у сфері запобігання і протидії корупції / В. П. Кохан // Питання боротьби зі злочинністю. - 2014. - Вип. 28. - С. 159-168. - Режим доступу: http://nbuv.gov.ua/UJRN/Pbzz 2014 $28 \quad 17$

6. Литвак О. М., Шумський П. В. Проблеми реформування кримінальної юстиції. // Сучасні проблеми реформування кримінальної юстиції в Україні: збірник матеріалів Інтернет-конференції (Київ, 28 листопада 2014 року). - К.: Національна академія прокуратури України, 2014. - С. 8-14[Електронний ресурс] - Режим доступу: http://napu.com.ua/wp-content/uploads/pdf/ KONFERENCE-krym_usticija.pdf

7. Міністерство юстиції та пріоритети його діяльності - [Електронний ресурс] - Режим доступу: https://minjust.gov.ua/m/ str 30804

8. Про Національне антикорупційне бюро: Закон України від 14 жовтня 2014 року № 1698-VII / Верховна Рада України // Відомості Верховної Ради (ВВР), 2014, № 47, ст.2051 (дата звернення 21.01.2020).

9. Про рішення Ради національної безпеки і оборони України від 15 лютого 2008 року «Про хід реформування системи кримінальної юстиції та правоохоронних органів»: указ, концепція Президента України від 08.04.2008 № 311/2008.// Офіційний вісник Президента України від 21.04.2008 р., № 12, стор. 79, стаття 486
10. Шакун В. Реформа кримінальної юстиції України у кримінологічному вимірі. // Ефективна система кримінальної юстиції як фактор сталого розвитку економіки : матеріали III панельної дискусії Другого Харків. міжнар. юрид. форуму, м. Харків, 27 верес. 2018 р. / [редкол.: В. Я. Тацій, Ю. Г. Барабаш, Б. М. Головкін та ін.] ; Нац. юрид. ун-т ім. Ярослава Мудрого. - Харків : Право, 2018. - C. $138-146$.

\section{Odnolko Inna. THE CONCEPT OF REFORMING THE CRIMINAL JUSTICE AUTHORITIES IN THE CONTEXT OF ANTI-CORRUPTION ACTIONS}

The article is devoted to the consideration of the concept of reforming criminal justice authorities in the context of combating corruption.

In the article it is analyzed the definitions of criminal justice according to different researchers, which reforms of criminal justice authorities have already been carried out during the independence of Ukraine and what results these reforms have achieved, marked mandatory tasks that should be put by any concept of criminal justice reform in the context of anti-corruption actions.

The author reveals the theoretical basis of the legal category of criminal justice authorities, and also analyzes in detail the place and importance of the National Anti-Corruption Bureau of Ukraine in the system of criminal justice authorities.

In the article the attention is drawn to the fact that reforming criminal justice agencies provides for a certain reload and introduction of new methods in activities. It was made the remark that the reform of criminal justice authorities could be the starting point for further reforms in our state in other areas of life.

To conclude it was determined that the result of the reform of criminal justice activities in the field of combating corruption, when applying any concept, should be the transformation of law enforcement agencies from purely punitive and pursuing harsh methods to authorities whose main purpose is to restore violated human rights and to prevent this violations at all.

Key words: corruption, anti-corruption actions, criminal justice authorities, reform, anticorruption legislation. 